G

COUNTERFUTURES

Left thought \& practice Aotearoa 


\title{
Nothing Sacred
}

\author{
Tim Corballis
}

\begin{abstract}
1 WHILE AGO, I came across a short piece by the Hungarian philosopher G. M. Tamás. In 'Telling the Truth Dabout Class', Tamás divides the Left, in good sectarian style, into Marxists and others (Rousseauists, as it turns out). What I found most immediately interesting in this piece was this claim: '[i]t is emotionally and intellectually difficult to be a Marxist since it goes against the grain of moral indignation which is, of course, the main reason people become socialists'. ${ }^{1}$ So Marxism is, perhaps surprisingly enough, incompatible with moral outrage, with anger, with the superiority of one's own position.
\end{abstract}

1 G. M. Tamás, 'Telling the Truth about Class', Socialist Register 42, 2006, p. 228. 
Although he seems to take sides with Marxism - and so to reignite all of those old antagonisms between Marxism and anarchism, or between class politics and identity politics, and so forth - I think that this is not at all we should be learning from Tamás. In fact, I am not even sure about the importance of Marxism here, aside from the way it acknowledges Marx as one of the originators of a kind of argument. Instead, I am interested in the quick demolition of all those structures, intellectual or cultural, that seem to guarantee our Leftist superiority. Whether we're Marxist or not, I think of the Left as a place where doubt, and self-doubt, are virtues. Perhaps we can think of the term 'Marxism', at least for now, as the name for something most of us are probably not used to understanding it as. It is the name for an insight into how two 'sides' - labour and capital, in the first instance, but just perhaps any two sides - are so tightly bound together as to be nearly one and the same. It is a name for thinking about the world that does not, after all, divide it into warring camps, into good and evil.

In the Marxian argument this is, at first, to do with work, and with the ways in which the worker and the capitalist are not enemies but allies. Both hope for businesses to keep going, one against the threat of lost investments, the other against the threat of unemployment. This is a very 'real world' alliance, about the binding of people's hopes on a day to day level, detached from any theory or any hope of revolution or utopia. We can take seriously the idea that it is capitalists who 'create work', even though they don't themselves do any. Without capital, our jobs are gone and our survival threatened - and all this, despite how much we may or may not hate our jobs and wish we didn't have to do them. The capitalist creates work in another sense too, insofar as the workplace is designed in the interests of capital itself. No one in their right mind would do half that stuff of their own accord. We do the work that they make available to us. 
The basic, day to day alliance of the worker and the capitalist is, I think, related to the rise of the ideas - amongst populists and the liberal left - of small business and personal entrepreneurship that seem to break down the very distinction. It also gives us a way to understand something of the world's widespread, small-c conservatism. Conservatism is fuelled at least in part by the desire not to change too much for fear that the things that sustain us, even if they exploit us at the same instant, might collapse. It is the mindset of the survivor, and not simply something to be judged.

So, broadly speaking, this is an argument that we are kept alive by the thing that exploits us - that we are part of it, that it creates us and destroys us at the same time. The Marxist is someone who thinks that who we are is defined by what we do. Workers are defined by their work, by their relation to capital, and their work is offered by capital, designed and conducted in the interests of capital. If there is an end to this, it is not in the triumph of a superior way of being, since our way of being is part and parcel of it.

That is, I suppose, an extreme argument. Can we really say that no part of ourselves is immune to the determining influence of capital? Isn't there a remainder, a spur of dissatisfaction, a residue of other cultures left untouched, a creative or militant spirit that evades domination? The question isn't solved by the simple insistence that there is. Capital, after all, loves its rebellions, and thrives on offering ways to escape from itself (mortgage, anyone?). But a question does remain as to how much of our activity - our paid and unpaid work, our recreation, the shape of our cities and communities and our lives - is made in the interests of that great need of capital to keep expanding. And the point is, by what measure can we know? How would we distinguish the freedoms and cultures we create for ourselves from the ones structured by capital? Can we tell the difference? Is our outrage itself, our superiority, our heroism, all part of it? 
Marxism is, in this context, a perspective on and a question about those aspects of our lives and our cultures that would change if we weren't doing so much for capital. This is why 'Marxism' means an argument for a lack of moral outrage, a lack of belief that one is better than some opponent. No fidelity or militancy can guarantee a distance from capital. The 'us' who might hope to win over it will, we may hope, not survive the victory. Rather than celebrating working class (or any other) culture, the Marxist asks us to wonder how much of our cultures we can endorse. If the 'Rousseauist' Left is interested in expanding its idea of 'the people' to include more and more - more cultures, more kinds of work, more ways of being - the Marxist points out that we must be prepared to distance ourselves from any of our current ways of being, no matter how accustomed to them we are.

Tamás makes the sober and familiar assessment that 'wherever successful proletarian movements or revolutions have taken place, they triumphed not against capitalism, but against quasi-feudal remnants of the old regime ....'2 I think we can count this not as pessimism but rather as the observation that capitalism doesn't get defeated in a war - or at least not in a war that involves the victory of one side over another. The challenge is to work out what alternative there is.

Feminists have known this lesson. I'm thinking, for example, of Shulamith Firestone's hope, not for the advancement of women, but for the thorough reinvention of the household and the community, and the eventual abolition of gender difference and of womanhood as a separate identity. ${ }^{3}$ The lesson might be there in a Treaty activism that aims, not just for Māori ownership of land, but of a thoroughgoing revision of the nature of land ownership, and of our relationships with and occupancy of plac-

2 Tamás, 'Telling the Truth about Class', p. 268.

3 Shulamith Firestone, The Dialectic of Sex, London and New York 2015. 
es. I'm not at all attached to the 'Marxist' label (or any other), but the set of thoughts I've presented here does attract me. Perhaps this is just a matter of temperament - I'm not much of a shouter - but it seems to me to suggest a Left attitude that is reluctant to name heroes, to endorse militant stances, or seek out new agents of history to replace the industrial proletariat. It is an argument too, I think, against guarantees found in theory or ontology. We should be prepared to doubt ourselves and our certainties - because, if it really were all to change, we might just not recognise the people we become. 
If you like what you have read, please subscribe or donate.

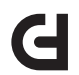

COUNTERF UTURES

Left thought \& practice Aotearoa

(C) Copyright Counterfutures 2016 